\title{
Review Paper on Soil Loss Estimation Using RUSLE
}

\section{Amare DG* \\ Department of Natural Resources Management, Debre Markos University Ethiopia}

*Corresponding author: Dessie Geta Amare, Department of Natural Resources Management, Debre Markos University, P.O Box: 18, Ethiopia, Tel: +251914823061; Email: dessiegt@gmail. com

\section{Review Article}

Volume 4 Issue 6

Received Date: September 06, 2020

Published Date: September 29, 2020

DOI: $10.23880 /$ jenr-16000213

\section{Abstract}

The soil erosion estimation procedure using RUSLE is adapted to the biophysical environment comprising soil, rainfall, topography, land cover and interactions between them. The estimation of soil loss using revised universal soil loss equation model implemented for estimating the mean annual soil loss. The aim of this review to show the estimated soil loss in different researcher using the same model. From these review the estimated mean annual soil loss is different in the same model (RUSLE). These is mainly the result of estimated annual soil loss is not the same per year as different researchers indicated in the table 1 because the mean annual soil loss is depend on the condition of the environment that means it dpend on soil erodibility, rainfall erosivity and slope steepnees and slope length of the area, land use of the area and management practice of investigation area. Some researchers of result indicate the same mean annual soil loss.

Keywords: RUSLE; Soil erosion; Soil loss

\section{Introduction}

Soil is the top layer of the earth's surface that is capable of sustaining life. Soil is very important to farmers, who depend on it to provide abundant, healthy crops each year. One major problem in agriculture is soil erosion. Soil erosion is the detachment and transportation of soil particles from a given site. Wind, water, ice, animals, and the use of tools by man are usually the main agents of soil erosion. It is a natural process which usually does not cause any major problems unless accelerated by human activities. It becomes a problem when human activitycauses it to occur much faster than under normal conditions. Water is the most important erosion agent and erodes most commonly as running water over land or in streams. Soil erosion is one of the most serious environmental and public health problems facinghuman society in the world. The loss of soil from land surface by erosion is widespread and adversely affecting the productivity of natural ecosystem as well as agricultural lands. Soil is a limited, strategic resource of huge social, economic and environmental significance. However, the use of inappropriate farming methods can lead to erosion and limit the productive capacity of the soil [1].

The soil erosion estimation procedure using RUSLE is adapted to the biophysical environment comprising soil, rainfall, topography, land cover and interactions between them. Important terrain characteristics influencing the mechanism of soil loss is length slope, shape and aspect. The impact of slope and aspect would play a significant role in runoff mechanism. More the slope, more the runoff and thus infiltration reduces. The runoff generated from slope will find a path nearby, and this would lead to erosion of soil as the velocity of the runoff increases. Rainfall simulation by slight portable rainfall simulators is deliberated to be a necessary method for consistent interrelated soil loss method for instance splash, basic runoff -precipitation processes, infiltration, losses sediment, nutrient movement [2].

\section{Objective}

To Review the result of estimated soil loss using RUSLE. To review the amount of soil loss by different researcher. 


\section{Journal of Ecology and Natural Resources}

To compare estimated mean annual soil loss.

\section{Litterateurs review}

Abate Ayalew [3], estimated the amount of soil loss in the Borena woreda of south wollo, Ethiopia. The revised universal soil loss equation model integrated with satellite remote sensing and geographic information system was used for erosion modeling. The input parameter in the model was soil type, annual average rainfall, and slope length and slop steepness, cover management, and support practice. Based on his study, the total soil loss from the area was found to be 2,661, 888 metric tons per year from 102756 hectare area.

V Prasannakumar [4] estimation of soil erosion risk within a small mountainous sub-watershed in Kerala, India. A comprehensive methodology that integrates Revised Universal Soil Loss Equation (RUSLE) model and Geographic Information System (GIS) techniques was adopted to determine the soil erosion vulnerability of a forested mountainous sub-watershed in Kerala, India. The spatial pattern of annual soil erosion rate was obtained by integrating geo-environmental variables in a raster based GIS method. GIS data layers including, rainfall erosivity $(\mathrm{R})$, soil erodability $(\mathrm{K})$, slope length and steepness (LS), cover management (C) and conservation practice (P) factors were computed to determine their effects on average annual soil loss in the area. The resultant map of annual soil erosion shows a maximum soil loss of 17.73 tons ha-1 year-1 with a close relation to grass land areas, degraded forests and deciduous forests on the steep sideslopes (with high LS ). The spatial erosion maps generated with RUSLE method and GIS can serve as effective inputs in deriving strategies for land planning and management in the environmentally sensitive mountainous areas.

Integration of remote sensing, RUSLE and GIS to model potential soil loss and sediment yield (SY). The aim of their study was to determine potential soil loss using the Revised Universal Soil Loss Equation (RUSLE) model and the sediment yield, in the Geographical Information Systems (GIS) environment within selected sub-catchments of Pahang River Basin. RUSLE was used to estimate potential soil losses and sediment yield by utilizing information on 10 rainfall erosivity $(R)$ using interpolation of rainfall data, soil erodibility $(K)$ using field measurement and soil map, vegetation cover $(C)$ using satellite images, topography (LS) using DEM and conservation practices $(P)$ using satellite images. The results indicated that the rate of potential soil loss in these sub-catchments ranged from very low to extremely high. The area covered by very low to low potential soil loss was about $1599 \%$, whereas moderate to extremely high soil loss potential covered only about $1 \%$ of the study area. Sediment yield represented only $1 \%$ of the potential soil loss. The sediment yield (SY) value in Pahang River turned out to be higher closer to the river mouth because of the topographic character, climate, vegetation type and density, andland use within the drainage basin.

Tadesse amsalu and Abebe mengaw [5] quantified and mapped soil loss by examining different topographic and anthropogenic factors for planning and implementing of sustainable soil conservation and management system in the Jabi Taninan werada, ANRS, Ethiopia. On the study, integrated geographic information system, remote sensing and multicriteria evaluation technique was used to quantify and map soil loss. The input parameters to estimate the amount of soil loss in the study were slope steepness and slope length, soil erodibility, rainfall erosivity, land management practice and cover management. They found that the mean annual soil loss from the area to be 30.6 tons ha-1year ${ }^{-1}$. which make total soil loss of $3,580,528$ ton per year from 116983 ha of land.

Gizachw Ayalew and Yihenew G.slassie [6] studied the soil loss rate (amount) of Guang watershed, Ethiopia with geographic information system and remote sensing. Revised universal soil loss equation, adapted Ethiopia condition, was used to estimate potential soil loss by utilizing information on rainfall erosivity using interpolation of rainfall data, soil erodibility using soil map, slope steepness and slope length using digital elevation model, land cover management and support practice factor using satellite image. Based on their study the mean and total annual soil loss of the watershed were 24.95 tons ha $^{-1}$ year $^{-1}$ and 8,732.5 tons year ${ }^{1}$ respectively. About 147.9 ha (64\%) of the watershed was categorized no erosion to slight erosion class which is under soil loss tolerance (SLT) value ranging from 5 to 11 ton ha ${ }^{1}$ year $^{-1}$ whereas the high soil loss potential covered about 206.1 ha (36\%). The study demonstrates that the revised universal soil loss equation and remote sensing provide a great advantage to spatially analyze multi-layer data.

Gizachw Ayalew [7] studied the soil loss rate (amount) of Zingin watershed, Ethiopia with geographic information system and remote sensing. Revised universal soil loss equation adapted for Ethiopia condition was used to estimate potential soil loss by utilizing information on rainfall erosivity using interpolation of rainfall data, soil erodibility using soil map, slope steepness and slope length using digital elevation model, land cover management and support practice factor using satellite image. Based on his study; the mean and total annual soil loss of the watershed were 9.1 tons ha ${ }^{-1}$ year $^{-1}$ and $57,750.15$ tons ha $^{-1}$ year ${ }^{-1}$ respectively. About 4909.63 ha $(78.31 \%)$ of the watershed was categorized no erosion to slight class which is under soil loss tolerance (SLT) value 


\section{Journal of Ecology and Natural Resources}

ranging from 5 to 11 tons ha $^{-1}$ year whereas the high soil loss potential covered about 1376.48 ha $(21.69 \%)$. The study demonstrates that the revised universal soil loss equation and remote sensing provide a great advantage to spatially analyze multilayer of data.

S abdul Rahaman, et al. [8] studied soil loss estimation on kala mini watershed in India. The revised universal soil loss equation (RUSLE) model is used to estimate soil loss. Field work household survey was conducted to identify major determinant of soil loss control. During the study six principal parameters were used to calculate soil loss per year such as rainfall factor, soil erodibility factor, slope length and slop steepness factor, crop management factor and support practice factor. The soil loss showed that the spatial variation that ranged from $4.5 \mathrm{Mg} / \mathrm{ha}$.year in forest to $65.9 \mathrm{Mg} / \mathrm{ha} /$ year in crop land.

A Adagna, et al. [9] studied the soil loss rate (amount) of north east wellega in the west Ethiopia with geographic information system and remote sensing. Revised universal soil loss equation adapted for Ethiopia condition was used to estimate potential soil loss by utilizing information on rainfall erosivity using interpolation of rainfall data, soil erodibility using soil map, slope steepness and slope length using digital elevation model, land cover management and support practice factor using satellite image. Based on his study; the mean and total annual soil loss of the watershed were 9.1 tons ha ${ }^{-1}$ year ${ }^{-1}$ and $65,750.15$ tons ha-1year ${ }^{-1}$ respectively. About 5909.63 ha (72.31\%) of the watershed was categorized no erosion to slight class which is under soil loss tolerance (SLT) value ranging from 5 to 11 tons ha ${ }^{-1}$ year whereas the high soil loss potential covered about 1376.48 ha $(28.69 \%)$. The study demonstrates that the revised universal soil loss equation and remote sensing provide a great advantage to spatially analyze multilayer of data.

Habtamu Sewnet and Amare Sewnet [10] estimated and mapped the mean annual soil loss by using revised soil loss equation and geographic information system and remote sensing technique in the Koga watershed, Ethiopia. The revised universal soil loss equation parameters were analyzed and integrated using raster calculator in the geo processing tool in Arc GIS 10.1 environment. Based on their study the mean annual soil loss ranged from 0 to 47 tons ha' ${ }^{1}$ year $^{-1}$.

BP Ganasri and H Ramesh [11,12] conducted assessment of soil erosion is useful in soil and water conservation and planning works in a watershed. Modeling can provide a quantitative and consistent approach to estimate soil erosion and sediment yield under a wide range of conditions. In the study, the soil loss model, Revised Universal Soil Loss Equation (RUSLE) integrated with GIS has been used to estimate soil loss in the Nethravathi Basin located in the southwestern part of India. The Nethravathi Basin is a tropical coastal humid area having a drainage area of $3128 \mathrm{~km} 2$ up to the gauging station. The parameters of RUSLE model were estimated using remote sensing data and the erosion probability zones were determined using GIS. The estimated rainfall erosivity, soil erodibility, topographic and crop management factors range from 2948.16 to $4711.4 \mathrm{MJ} / \mathrm{mm} \$$ ha1hr1/year, 0.10 to $0.44 \mathrm{t}$ ha1 $\$$ MJ1\$mm1, 0 to 92,774 and 0 to 0.63 respectively. The results indicate that the estimated total annual potential soil loss of about 473,339 tons/ha-1/year- 1 is comparable with the measured sediment of 441, $870 \mathrm{t} / \mathrm{yr}$ during the water year 2002 and 2003. The predicted soil erosion rate due to increase in agricultural area is about 14,673.5 t/yr. The probability zone map has been derived by the weighted overlay index method indicate that the major portion of the study area comes under low probability zone and only a small portion comes under high and very high probability zone. The results can certainly aid in implementation of soil management and conservation practices to reduce the soil erosion in the Nethravathi Basin.

\section{Conclusion}

Estimating soil loss using revised universal soil loss equation model implemented for estimating the mean annual soil loss. From these review the estimated mean annual soil loss is different in the same model (RUSLE). The main cause for the variation of these estimated annual mean annual soil loss is land use of the investigations area for instance $S$ abdul Rahaman, et al. [8] their investigation indicates mean annual soil loss of the area is $4.5 \mathrm{Mg} / \mathrm{ha}$. year in forest to $65.9 \mathrm{Mg} /$ ha/year in crop land. From the review the maximum mean annual soil loss is 30.6 tons ha-1year the cause the natural condition of the environment ie rainfll, soil type, topography, land use type and management practice. The result of estimated annual soil loss is not the same per year as different researchers indicated in the table 1 because the mean annual soil loss is depend on the condition of the environment that means it depend on soil erodibility, rainfall erosivity and slope steepnees and slope length of the area, land use of the area and management practice of investigation area. Some researchers of result indicate the same mean annual soil loss Gizachw Ayalew [7] 9.1 tons ha ${ }^{-1}$ year and A Adagna [9] 9.1 tons ha- ${ }^{-1}$ year but the total estimated annual soil loss is different Gizachw Ayalew [7] 57,750.15 tons ha $^{-1}$ year $^{-1}$ and A Adagna [9] 65,750.15 tons ha ${ }^{-1}$ year $^{-1}$ these is why because the total study area coverage of investigation. 
Journal of Ecology and Natural Resources

\begin{tabular}{|c|c|c|c|c|}
\hline \multirow{2}{*}{ No } & \multirow{2}{*}{ Authors } & \multirow{2}{*}{$\begin{array}{l}\text { Model } \\
\text { used }\end{array}$} & \multicolumn{2}{|c|}{ Estimated soil loss } \\
\hline & & & Total & Average \\
\hline 1 & Abate Ayalew [3], & RUSLE & $\begin{array}{l}\text { 2,661, } 888 \text { metric tons per year } \\
\text { from } 102756 \text { hectare area. }\end{array}$ & 25.9 ton/year/ha \\
\hline 2 & V Prasannakumar [4] & RUSLE & - & 17.73 tons ha ${ }^{-1}$ yearr $^{-1}$ \\
\hline 3 & Tadesse amsalu and Abebe mengaw [5] & RUSLE & - & 30.6 tons ha ${ }^{-1}$ year $^{-}$ \\
\hline 4 & Gizachw Ayalew and Yihenew G. slassie [6] & RUSLE & - & 24.95 tons ha $^{-1}$ year $^{-1}$ \\
\hline 5 & Gizachw Ayalew [7] & RUSLE & $57,750.15$ tons ha ${ }^{-1}$ year $^{-1}$ & 9.1 tons ha-1 year $^{-1}$ \\
\hline 6 & S Abdul Rahaman [8] & RUSLE & - & $\begin{array}{l}4.5 \mathrm{Mg} / \text { ha.year in forest to } \\
65.9 \mathrm{Mg} / \mathrm{ha} / \text { year in crop land. }\end{array}$ \\
\hline 7 & A Adagna [9] & & $65,750.15$ tons $^{-1}$ year $^{-1}$ & 9.1 tons ha $^{-1}$ year \\
\hline 8 & Habtamu Sewnet and Amare Sewnet [10] & RUSLE & & 0 to 47 tons ha $^{-1}$ year $^{-1}$ \\
\hline 9 & BP Ganasri and Gajanan K Khadse $[11,12]$ & RUSLE & 473,339 tons/ha- $1 /$ year- 1 & - \\
\hline
\end{tabular}

\section{References}

1. Lal R (2001) Soil degradation by erosion. Land Degradation Development 12(6): 519-539.

2. Arnaez J, Lasanta T, Ruiz-Flaño P, Ortigosa L (2007) Factors affecting runoff and erosion under simulated rainfall in Mediterranean vineyards. Soil and Tillage Research 93(2): 324-334.

3. Abate S (2011) Estimating soil loss rates for soil conservation planning in the Borena woreda of South Wollo highlands, Ethiopia. Journal of Sustainable Development in Africa 13(3): 1520-5509.

4. Prasanna kumar V, Remortel VR, Hamilton M, Hickey R (2011) Estimating the LS factor for RUSLE through iterative slope length processing of digital elevation data. Cartography 30(1): 27-35.

5. Amsalu T, Mengaw A (2014) GIS Based Soil Loss Estimation Using RUSLE Model: The Case of Jabi Tehinan Woreda, ANRS, Ethiopia. Natural Resources 5: 616-626.

6. Ayalew G, Slassie YG (2015) Estimating Soil Loss Using Universal Soil Loss Equation (USLE) for Soil Conservation planning at Medego Watershed, Northern Ethiopia. Journal of American Science 5(1): 58-69.

7. Gizachew Ayalew (2015) A Geographic information system based soil loss and sediment estimation in
Zingin watershed for conservation planning, highlands of Ethiopia. International Journal of Science Technology and Society 3(1): 28-35.

8. S. Abdul Rahaman, Aruchamy S, Jegankumar R, Abdul Ajeez S (2015) Estimation of annual average soil loss, based on rusle model in kallar watershed, bhavani basin, tamil nadu, india, ISPRS Annals of the Photogrammetry, RemoteSensing and Spatial Information Sciences, Volume II-2/W2, 2015 Joint International Geoinformation Conference 2015, 28-30 October 2015, Kuala Lumpur, Malaysia.

9. Adugna A, Abegaz A, Cerdà A (2015) Soil erosion assessment and control in Northeast Wollega, Ethiopia. Solid Earth Discuss 7(4): 3511-3540.

10. Habtamu S, Amare S (2016) Estimation of Soil Erosion Dynamics in the Koshi Basin Using GIS and Remote Sensing to Assess Priority Areas for Conservation, International Centre for Integrated Mountain Development, GPO Box 3226, Kathmandu, Nepal.

11. Ganasri BP, Ramesh H (2014) Assessment of soil erosion by RUSLE model using remote sensing and GIS - A case study of Nethravathi Basin. Geosciences Frontiers 7(6): 953-961.

12. Gajanan K Khadse, Ritesh Vijay, Pawan K Labhasetwar (2015) Prioritization of catchments based on soil erosion using remote sensing and GIS. Environ Monit Assess 187(6): 333. 